\title{
THE ROLE OF HEALTH INFORMATION MANAGEMENT PROFESSIONALS IN THE IMPELENTATION OF INA-CBGS IN BLUD RSU H. BOEJASIN PELAIHARI
}

\author{
Dedy Kurniawan', Hosizah² \\ ${ }^{1}$ Program Studi RMIK-STIKES Husada Borneo Banjarbaru, \\ ${ }^{2}$ Ka.Umum aptiRMIK-Dosen Fakultas Ilmu-ilmu Kesehatan Universitas Esa Unggul, \\ dedymellon@ymail.com, hozisah@esaunggul.ac.id, ozi19sah@ymail.com
}

\begin{abstract}
Backgrounds:Jamkesmas refers to medical assistance program designed to meet the needs of low income people which is funded by the federal goverment. The prospective payment systems is adopted as payment method is called an Indonesia Case Based Groups (INA-CBGs). In an INA-CBGs, an accurate and complete clinical data is required. While the primary function of health information department is providing that an accurate and complete clinical data for billing, In BLUD RSU H. Boejasin Pelaihari, HIM professional is not exist yet so provide clinical data for billing is carried out by other health workforce. No one of coders' process for review of clinical data, the billing process, and the payers' reimbursement to the healthcare facilities.

Objectives:This study aims toinvestigate the role ofhealth informationmanagement professionals in INACBGs implementation

Methods:This descriptive research study was performed to describe INA-CBGs implementation. The study population all of the health workforce involve in INA-CBGs implementation, sample are coder and independent verificator. An interview guide and checklist were used as instrument for observation and interview.

Results: On the flow and procedures of INA-CBGs reimbursement process shows redundancy verification at claim document so take long times claim process. The three activities include data entry, grouping and recapitulation to be done of two health workforces, they are should be only done one health workforce.The eleven workforces in case-mix group member include hospital director, the head of services, the physicians, the head of medical record department, pharmacistand the services staff. Coded Diagnosis and procedures data is verified by independent verificator, whose not member of case-mix group. It is should not be needed, that is primary function of health information department or medical record department for providing accurate and complete clinical data for billing. The role a HIM professional are increase revenue potential by assuring accurate coding supported by documentation, improved cash flow by first time processing with few denials and appeals required etc.No case-mix team and no expenditure for them.
\end{abstract}

Keywords: Health Information Management (HIM), HIM Professional, INA-CBGs, Medical Record, Reimbursement Process, Coder

\section{PENDAHULUAN}

Kesehatan adalah hak dasar setiap individu dan semua warga negara berhak mendapatkan pelayanan kesehatannya termasuk masyarakat miskin, untuk itu peran pemerintah dalam mewujudkan itu sangatlah penting. Terbitnya Undang-Undang SJSN Nomor 40 tahun 2004 tentang Sistem Jaminan Sosial Nasional menjadi suatu bukti yang kuat bahwa pemerintah dan pemangku kepentingan terkait memiliki komitmen yang besar untuk mewujudkan kesejahteraan sosial bagi seluruh rakyatnya. SJSN sebagai salah satu bentuk perlindungan sosial pada hakekatnya bertujuan untuk menjamin seluruh rakyat agar dapat memenuhi kebutuhan dasar hidupnya yang layak.

Dalam rangka meningkatkan akses dan mutu pelayanan kesehatan sebagai kebutuhan dasar, khususnya bagi masyarakat miskin, Kementerian Kesehatan sejak tahun 2005 telah melaksanakan program jaminan kesehatan sosial, dimulai dengan program Jaminan Pemeliharaan Kesehatan bagi Masyarakat Miskin/JPKMM atau lebih dikenal dengan program Askeskin (2005-2007) yang kemudian berubah nama menjadi program Jaminan 
Dedy, dkk. The Role og Health Information Management

Kesehatan Masyarakat (Jamkesmas) sejak tahun 2008 sampai dengan sekarang.

Pelaksanaan program Jamkesmas tersebut merupakan upaya untuk menjaga kesinambungan pelayanan kesehatan bagi masyarakat miskin dan tidak mampu dengan menggunakan prinsip asuransi kesehatan sosial yang merupakan masa transisi sampai dengan diserahkannya program jaminan kesehatan kepada Badan Penyelenggara Jaminan Sosial (BPJS) Kesehatan sesuai Undang- Undang Nomor 24 Tahun 2011 tentang Badan Penyelenggara Jaminan Sosial.

Upaya untuk kendali biaya dan mutu, program Jamkesmas menggunakan sistem pembayaran dengan tarif paket yang dinamakan Indonesia Case Base Groups (INA-CBGs) untuk pelayanan di rumah sakit. Pada awalnya sistem tersebut di namakan Indonesia Diagnostic Related Groups (INA-DRGs) namun karena lisensi maka berganti nama menjadi INA-CBGs pada 1 oktober 2010. Sistem pembayaran dengan tarif INA-CBGs dimana pemberi pelayanan kesehatan (PPK) akan menerima sejumlah imbalan yang besarnya sesuai dengan diagnosis penyakit. Dalam implementasi INA-CBGs diperlukan kelengkapan dan keakuratan data klinis dalam dokumen rekam medis, hal itu sejalan dengan fungsi utama dari unit kerja manajemen informasi kesehatan yaitu menyediakan catatan medis yang lengkap dan akurat untuk perawatan pasien, menyediakan data klinis yang lengkap dan akurat untuk proses penagihan dan menyediakan informasi klinis untuk merencanakan jenis layanan fasilitas kesehatan (Huffman, 1994).

Di dalam Reimbursement, peran profesional MIK sangat penting dalam pemberian kode diagnosis penyakit dan tindakan. Kualitas koding yang dihasikan tergantung padabeberapa faktor yaitu Pelatihan yang memadaibagi semua orangyang terlibatdalam proseskoding, AcuanCukupdan sumber dayapendukung yang lengkap, dokumentasi klinisyang akurat danlengkap, adanya dukunganpara manajer seniortentangfungsikoding dan sebuahrencana perbaikan kinerjauntuk fungsikodingyang menjaminprosesperbaikan kualitas berkesinambungan, sehingga Ketika semuakomponen itu ada, kualitas kodedata klinisdapat dievaluasimeliputikeandalan, validitas, kelengkapan dan ketepatan waktu. Kualitas data yangdiberi kodebergantungpada kualitasdokumentasiklinis (Latour-Maki,2010). karena syarat dan aturan yang komplek dapat mempengaruhi proses koding informasi kesehatan untuk itu dalam proses koding, profesional MIK memerlukan standar etika koding sertaharus bekerja samadengandokter dantenaga kesehatan untuk meningkatkan kualitasnya (AHIMA, 2008). Dampak dari ketidaklengkapan data akan memperlambat proses klaim sehingga bisa terjadinya keterlambatnya penggantian biaya oleh pihak ke tiga dan itu menjadi tanggung jawab manajer MIK (Huffman,1994).

Di BLUD RSU H. Boejasin Pelaihari, sistem INA-CBGs sudah berlangsung sejak 2010 yaitu sejak diberlakukannya INA-CBGs di Indonesia dari mulai versi 1.6 hingga sekarang. Pada proses pelaksanaan INA-CBGs tahapan kodefikasi diagnosis dan tindakan dilakukan oleh petugas koder dengan latar pendidikan Sarjana Kesehatan Masyarakat (bukan Profesional MIK). Rekam medis pasien Jamkesmas setelah pulang rawat dibawa langsung ke ruang Jamkesmas untuk dilakukan koreksi kelengkapan oleh bagian Jamkesmas, setelah itu dikirim ke bagian rekam medis untuk dilakukan pengkodingan oleh tenaga koder, setelah selesai di koding dikembalikan lagi ke ruang Jamkesmas untuk dilakukan pengklaiman, hal ini masih belum sesuai dengan Pedoman Pelaksanaan Jamkesmas. Merujuk hal itu maka peneliti tertarik melakukan penelitian dengan judul "Peran Profesional MIK dalam Implementasi INA-CBGs di BLUD RSU H. Boejasin Pelaihari”.

\section{Peran Profesional MIK}

MenurutAHIMAdalam buku konsep profesional MIK yang berjudul A New View of HIM Introducing the Core Model, Peran profesional MIK diidentifikasi untuk setiap unsur-unsurdari inti pekerjaaannya. Salah satubagian fungsi dan peran profesional MIK adalah Meningkatanpotensipendapatandengan memastikan koding yang akurat dengan didukung olehdokumentasi.

\section{Pengertian Peran}

Menurut Kamus Besar Bahasa Indonesia, peran adalah pemain atau perangkat tingkah yang diharapkan dan dimiliki oleh orang yang berkedudukan.

Profesi rekam medis memiliki peran yang setara dengan tenaga kesehatan lain, jabatan fungsional 
untuk perekam medis telah diberlakukan sejak 1 Oktober 2003, dengan syarat minimal memiliki ijazah Diploma III Ilmu Rekam Medis. Sesuai dengan Keputusan Menteri Pendayagunaan Aparatur Negara tentang Jabatan Fungsional Perekam Medis dan Angka Kreditnya Nomor. 135/KEP/M. PAN/12/2002.

Profil kelulusan DIII Ahli Madya Perekam Medis dan Informasi Kesehatan mulai tahun 2011 memiliki peran dan fungsi antara lain:

a. Manajer Unit Kerja Rekam Medis dan Informasi Kesehatan

b. Clinical Coder

c. Pengelola Informasi Kesehatan

d. Sebagai mitra perancang sistem informasi kesehatan

e. Sebagai mitra peneliti

\section{Manajemen Informasi Kesehatan}

Alasan utama perubahan rekam medis menjadi manajemen informasi kesehatan karena tugas utama profesi di masa depan adalah melakukan manajemen "informasi" kesehatan yang berasal dari berbagai sumber informasi aktivitas pelayanan kesehatan. Dengan adanya paradigma baru, praktisi MIK harus mengerti tentang peranannya yang besar dalam dunia pelayanan kesehatan.Lahirnya paradigma baru rekam medis yang dinamakan sebagai manajemen informasi kesehatan (MIK) merupakan dampak positif dari revolusi teknologi informasi dan komunikasi (TIK). Revolusi teknologi informasi saat ini sangat berdampak pada perkembangan dan perubahan konsep dan tata cara berkomunikasi.

Dalam praktek tradisional MIK bahwa yang dikerjakan masih terfokus pada bentuk fisik unit kerjadan rekam medis saja. sementara dengan adanya paradigma baru manajemen informasi yang bertugas melaksanakan praktik manajemen berorientasi informasi, dengan artian peran profesional MIK yang dikembangkan saat ini adalah sebagai manajer MIK, spesialis data klinis (SDK), koordinator informasi pasien (KIP), manajer kualitas data, manajer keamanan informasi, administrator sumber data dan sebagai riset dan spesialis penunjang keputusan (Hatta,2010).

\section{Pengertian Profesional MIK}

Profesional MIK adalah seseorang yang telah menerima pelatihan profesional pada jenjang pendidikan bidang manajemen data kesehatan dan alur informasi sistem pelayanan kesehatan, yang bertugas sebagai administrator informasi kesehatan yang berkewajiban untuk mengumpulkan, mengintegrasikan dan menganalisis data pelayanan kesehatan, mengolah informasi, menata sumber informasi bagi kepentingan riset, perencanaan, memberikan jasa dan evaluasi pelayanan kesehatan yang terintegrasi (Hatta, 2010).

\section{Sistem INA-CBGs}

Sistem INA-CBGs (Indonesia Case Base Groups) adalah aplikasi yang digunakan sebagai aplikasi (software grouper) pengajuan klaim Rumah Sakit, Puskesmas dan semua Penyedia Pelayanan Kesehatan (PPK) bagi masyarakat miskin atau peserta Jamkesmas di Indonesia. INA-CBGs merupakan kelanjutan dari aplikasi INA-DRG yang lisensinya berakhir pada akhir tahun 2010 dan terus disempurakan (Manlak Jamkesmas, 2012).Dalam artian INA-CBGs merupakan persamaan dari aplikasi DRGs dengan mengadopsi sistem aplikasi DRGs yang lebih disempurnakan.

Diagnostic Related Groups (DRGs) merupakan jenis pembayaran prospektif, pengertian DRGs dapat disederhanakan dengan cara pembayaran dengan biaya satuan per diagnosis, bukan biaya satuan per jenis pelayanan medis maupun nonmedis yang diberikan kepada pasien. Dalam pembayaran INA-CBGs baik rumah sakit maupun pihak pembayar tidak lagi merinci tagihan berdasarkan rincian pelayanan yang diberikan, melainkan hanya dengan menyampaikan diagnosis pasien waktu pulang dan memasukan kode INA-CBGs untuk diagnosis tersebut.Besarnya tagihan untuk diagnosis tersebut telah disepakati oleh seluruh rumah sakit di suatu wilayah dengan pihak provider/asuransi atau yang ditetapkan oleh pemerintah sebelumnya. (Hatta, 2010).

\section{Unsur-Unsur Kualitas Koding}

Kualitas dari kode data klinistergantung padasejumlah faktor, termasuk (Latour-Maki, 2010) :

a. Pelatihan yang memadai bagi semua orangyang terlibat dalam proses koding, termasuk koder, koding pengawas, dokter dan tenaga keuangan.

b. Acuandan sumber daya pendukung yang Cukup, termasuk buku-buku kodingyangup-to-date, serta dalam penerbitan pedoman resmi (yaitu, Koding Klinik untuk ICD-9 CM dan pedoman pendukung lainnya) dan perangkat lunak pendukung lainnya.

c. Dokumentasi klinisyang akurat danlengkap yang mencakup setiap kondisi yang bersangkutan danpelayanan yang diberikan kepadapasien. 
Dedy, dkk. The Role og Health Information Management

d. Adanya dukunganpara manajer senior, yang harus memahami betapa pentingnya fungsi koding adalah untuk keberlangsungan organisasiyang terus menerus.

e. Sebuah rencana perbaikan kinerja untuk fungsikoding yang menjamin proses perbaikan kualitas berkesinambungan.

Ketika semua komponenini timbul, kualitas kodedata klinisdapat dievaluasisesuai dengan unsurunsur berikut:

a. Keandalan yaitu sejauh manadata dapat diperbanyak oleh pengukuran selanjutnya atau tes (misalnya, kode data klinis dianggap dapat diandalkan ketika beberapa koder menetapkan kode yang sama untuk dicatat).

b. Validitas yaitu sejauh manadatadikodekansecara akurat mencerminkandiagnosa dan prosedur pasien.

c. Kelengkapan yaitu sejauh manadata dikodekan mewakili semua diagnosa pasien atau prosedur yang relevan.

d. Ketepatan waktu yaitusejauh manadata dikodekan tersedia dalam jangka waktu yang diperlukan untuk tujuan penagihan, pendukung keputusan dan kegunaan lainnya.

\section{Kepatuhan Dalam Pengkodean}

Mengacu pada etika pengkodean dan keinginan mencapai kualitas tinggi, data yang terkode sangat membantu penerbitan rincian tagihan biaya rawat yang tepat dan mengurangi resiko manajemen fasilitas asuhan kesehatan terkait. Maka direkomendasikan komponen perancangan program kepatuhan yang efektif, yaitu (Hatta, 2010):

a. Adakan auditing dan monitoring internal

b. Implementasikan compliance dan standar praktik

c. Tentukan kontak person compliance

d. Adakan pelatihan dan pendidikan yang tepat

e. Tanggap dengan tepat atas keluhan yang terdeteksi dan mengembangkan tindakan koreksinya

f. Kembangkan jalur komunikasi yang terbuka

g. Kuatkan standar disiplin dalam pedoman tertulis

Bagian penting dalam audit internal yaitu audit pengkodean diagnosis yang merupakan proses pemeriksaan pendokumentasian rekam medis untuk memastikan bahwa proses pengkodean dan hasil pengkodean diagnosis tersebut akurat, presisi dan tepat waktu sesuai dengan aturan dan kebijakan yang berlaku. Adapun tujuan dari audit pengkodean diagnosis (Hatta, 2010): a. Mereview dan menganalisis kesalahan yang ditemukan dan berusaha menelusuri sumbernya.

b. Membandingkan informasi yang dihasilkan pengkode (di lembar resume pulang) saat dikode dengan informasi yang tertera di lembar-lembar catatan klinik saat pengkodean dijalankan

c. Mereview informasi untuk suatu akurasi dan dikaitnya dengan standar nasional yang diberlakukan

d. Mengidentifikasi area praktik pengkodean yang perlu peningkatan

e. Mereview kualitas dan kelengkapan sumber informasi (lembar resume dan lembar catatan klinik)

f. Mempertemukan perbedaan pendapat antara tenaga medis dengan pengkode.

g. Membuat rekomendasi, bila perlu, untuk meningkatkan kualitas dan kode data klinis.

\section{METODE PENELITIAN}

Jenis penelitian yang digunakan adalah deskriptif studi atau penelaah kasus (case study) dengan cara meneliti suatu permasalahan melalui suatu kasus yang terdiri dari unit tunggal.Variabel penelitian ini adalah peran profesional manajemen informasi kesehatan.

Populasi dari penelitian ini adalah seluruh Sumber Daya Manusia (SDM) yang terlibat dalam proses klaim sistem INA-CBGs yang diterapkan di BLUD RSU H. Boejasin Pelaihari.Sampel pada penelitian ini adalah Koder dan Verifikator Independen yang terlibat dalam proses pengklaiman INA-CBGs, dengan teknik Purposive Sampling. Instrumen penelitian terdiri dari :pedoman wawancara, pedoman observasi.

Analisis data yang digunakan dalam penelitian ini adalah secara deskriptif yaitu dengan cara mendeskripsikan tentang keadaan proses klaim INA-CBGs diBLUD RSU H. Boejasin Pelaihari.

\section{HASIL}

Alur dan prosedur proses klaim sistem INA-CBGs di BLUD RSU H. Boejasin Pelaihari dibentuk berdasarkan Surat Keputusan Direktur BLUDRSU H. Boejasin Pelaiharitentang Tim Pengelola Sistem Case-Mix Program Jamkesmas Di BLUD RSU H. BoejasinPelaihari Tahun Anggaran 2012. Alur dan prosedur ini dijabarkan dalam bentuk narasi, yang 
mana pada alur dan prosedur ini melibatkan berbagai bidang mulai dari Bagian Pelayanan, Instalansi Rekam Medis, bagian Jamkesmas sampai dengan Verifikator Independen, seperti yang dijabarkan dalam skema atau bagan sebagai berikut:

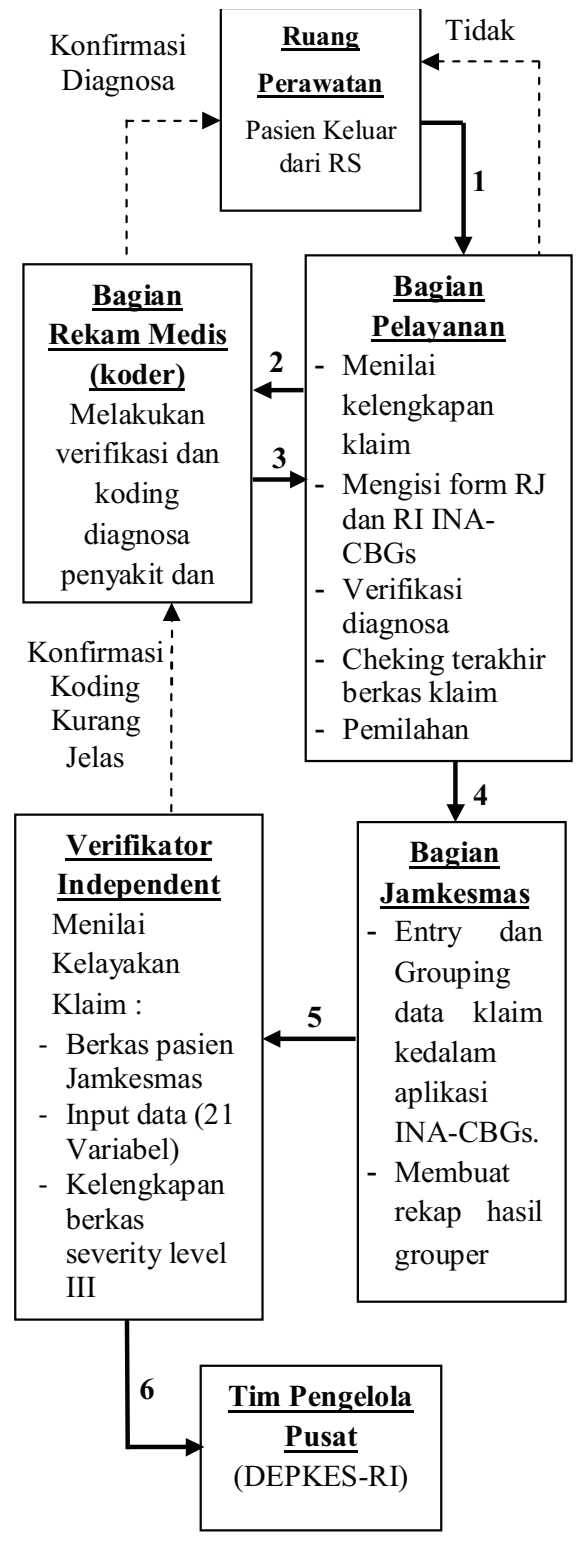

\section{Bagan atau Skema 1. Alur dan Prosedur Proses Klaim Sistem INA-CBGs}

Sumber daya manusia yang terlibat di dalam proses klaim sistem INA-CBGs dibentuk berdasarkan surat keputusan yang sama, dengan jumlah keseluruhan SDM yang terlibat secara langsung maupun tidak secara langsung didalam proses klaim yaitu berjumlah 11 orang.
Tabel 1: Tim Case Mix (INA-CBGs) di BLUD RSU H. BoejasinPelaihari Tahun 2012

\begin{tabular}{|c|c|c|c|}
\hline No & Tim & $\begin{array}{c}\text { Jabatan Di } \\
\text { RS }\end{array}$ & $\begin{array}{c}\text { Tugas/Tanggung } \\
\text { Jawab }\end{array}$ \\
\hline 1 & Pembina & $\begin{array}{l}\text { Direktur } \\
\text { Rumah Sakit }\end{array}$ & $\begin{array}{l}\text { Sebagai penanggung } \\
\text { jawab semua kegiatan } \\
\text { pelayanan Jamkesmas }\end{array}$ \\
\hline 2 & Pengarah & $\begin{array}{l}\text { Kepala } \\
\text { Bidang } \\
\text { Pelayanan }\end{array}$ & $\begin{array}{l}\text { Mengkoordinasikan } \\
\text { kegiatan Jamkesmas, } \\
\text { mulai dari pelayanan } \\
\text { kepada pasien sampai } \\
\text { dengan evaluasi } \\
\text { pelayanan Jamkesmas }\end{array}$ \\
\hline 3 & Ketua & Dokter di RS & $\begin{array}{l}\text { Mengendalikan semua } \\
\text { kegiatan Tim Case- } \\
\text { Mix Jamkesmas agar } \\
\text { berjalan dengan lancar, } \\
\text { mengontrol pelaksanaan } \\
\text { pelayanan dan pelaporan } \\
\text { dari seluruh kegiatan } \\
\text { Jamkesmas. }\end{array}$ \\
\hline 4 & Sekretaris & $\begin{array}{l}\text { Bagian } \\
\text { Jamkesmas }\end{array}$ & $\begin{array}{l}\text { Mengendalikan secara } \\
\text { administrasi seluruh } \\
\text { kegiatan Jamkesmas, } \\
\text { membuat perencanaan, } \\
\text { klaim dan pelaporan } \\
\text { Jamkesmas }\end{array}$ \\
\hline 5 & Anggota & $\begin{array}{l}\text { Humas } \\
\text { Jamkesmas }\end{array}$ & $\begin{array}{l}\text { Melakukan verifikasi } \\
\text { diag-nosis dan tindakan } \\
\text { medis } \\
\text { S e ba ga i H u mas } \\
\text { Jamkesmas } \\
\text { Membuat rekap } \\
\text { pembagian jasa dan } \\
\text { menyerahkan kedalam } \\
\text { sistem remunerasi } \\
\text { Membuat laporan } \\
\text { kegiatan Jamkesmas }\end{array}$ \\
\hline 6. & Anggota & $\begin{array}{l}\text { Kepala } \\
\text { Bagian } \\
\text { Rekam } \\
\text { Medis }\end{array}$ & $\begin{array}{l}\text { Memverifikasi dan } \\
\text { memberi kode INA- } \\
\text { CBGs dalam berkas } \\
\text { klaim yang diajukan } \\
\text { oleh ruangan/poliklinik }\end{array}$ \\
\hline 7 & Anggota & $\begin{array}{l}\text { Staf Bagian } \\
\text { Pelayanan }\end{array}$ & $\begin{array}{l}\text { M e r e n c n a k a } n \\
\text { kebutuhan obat-obatan } \\
\text { dan alat medis habis } \\
\text { pakai (AMHP) }\end{array}$ \\
\hline 8 & Anggota & $\begin{array}{l}\text { Staf Bagian } \\
\text { Pelayanan }\end{array}$ & $\begin{array}{l}\text { Membuat laporan } \\
\text { pembagian jasa } \\
\text { Membagikan jasa } \\
\text { pelayanan }\end{array}$ \\
\hline 9 & Anggota & $\begin{array}{l}\text { Staf Bagian } \\
\text { Pelayanan }\end{array}$ & $\begin{array}{l}\text { - Menerima pengem- } \\
\text { balian berkas dari } \\
\text { tempat pelayanan } \\
\text { untuk disampaikan } \\
\text { kebagian klaim } \\
\text { - Menyampaikan ber- } \\
\text { kas klaim ke bagian } \\
\text { koder } \\
\text { - Melakukan cheking } \\
\text { terakhir terhadap } \\
\text { berkas yang sudah } \\
\text { dikoding dan memi- } \\
\text { lahnya sesuai keadaan } \\
\text { tempatnya diberikan } \\
\text { pelayanan }\end{array}$ \\
\hline
\end{tabular}


Dedy, dkk. The Role og Health Information Management

\begin{tabular}{|c|c|c|c|}
\hline 10 & Anggota & $\begin{array}{l}\text { Bagian } \\
\text { Jamkesmas }\end{array}$ & $\begin{array}{l}\text { - Melakukan entry data } \\
\text { ke sistem software } \\
\text { INA-CBGs } \\
\text { - Membuat hasil } \\
\text { pelaksanaan program } \\
\text { pe n d a m p in g } \\
\text { penyelenggaraan } \\
\text { jamkesmas }\end{array}$ \\
\hline 11 & Anggota & $\begin{array}{l}\text { Bagian } \\
\text { Jamkesmas }\end{array}$ & $\begin{array}{l}\text { Melakukan group- } \\
\text { ing data yang sudah } \\
\text { di koding ke dalam } \\
\text { software INA-CBGs } \\
\text { - Membuat rekap hasil } \\
\text { grouper untuk dima- } \\
\text { sukkan dalam pem- } \\
\text { bagian jasa pelayanan }\end{array}$ \\
\hline
\end{tabular}

Didalam proses klaim sistem INA-CBGs di BLUD RSU H. Boejasin Pelaihari, peran instalansi rekam medis dalam hal ini sebagai petugas koding (koder) dengan tugas yaitu memverifikasi dan memberi kode INA-CBGs dalam berkas klaim yang diajukan oleh ruangan/poliklinik. Saat ini kualifikasi koder dengan latar belakang pendidikan koder tersebut adalah Sarjana Kesehatan Masyarakat (SKM). Pada kenyataannya hasil koding diagnosis penyakit dan tindakan diverifikasioleh verifikator independen sedangkan pada tabel tertulis verifikasi koding semestinya dilakukan oleh bagian rekam medis. Prosedur pengkodingan yang dilakukan oleh koder berdasarkan Standar Operasional Prosedur (SOP) yang berlaku di rumah sakit.Berdasarkan hasil wawancara yang dilakukan peneliti terhadap koder, bahwa pengalaman dalam melakukan kodefikasi diagnosis dan tindakan yaitu sejak menjabat sebagai staf rekam medis dan juga mendapat berbagai pelatihan tentang kodefikasi diagnosis dan tindakan, serta pelatihan tentang INA-DRGs dan INA-CBGs yang memungkinkan koder dapat melakukan proses kodefikasi dengan baik. Namun terlepas dari itu, koder juga menjelaskan masih terdapat beberapa kendala yang di hadapi selama melakukan proses pemberian kode diagnosis dan tindakan pada berkas klaim yaitu penulisan diagnosis dan tindakan oleh dokter yang belum sesuai dengan standar diagnosis ICD-10 serta tulisan dokter yang tidak terbaca (illegible).

\section{PEMBAHASAN}

\section{Alur dan Prosedur Proses Klaim Sistem INA-CBGs}

Dari hasil penelitian masih terdapat ketidaksesuaian antara alur dan prosedur klaim dirumah sakit dengan alur prosedur administrasi klaim pedoman pelaksanaan jamkesmas tahun 2012, yaitu pada tahap awal setelah pasien keluar dari RS, Rekam Medis pasien tersebut diperiksa atau diverifikasi kelengkapan persyaratan klaim oleh bagian pelayanan setelah itu berkas di kirim ke Instalansi Rekam Medis untuk dilakukan pengkodingan diagnosis dan tindakan oleh Koder. Selanjutnya dilakukan pemeriksaan ulang oleh bagian pelayanan sehingga akan terdapat 3 kali pemeriksaan sebelum di kirim ke Tim Pengelola Pusat.

Alur dan prosedur di dalam sistem pembayaran prospektif INA-CBGs tsb, peran profesiona MIK belum optimal karena fungsi audit koding belum berjalan sebagai mana mestinya.

Sesuai dengan teori yang ada unit kerja RMIK atau Unit MIK harus berperan aktif dalam implementasi sistem INA-CBGs, yaitu menyediakan data klinis yang lengkap dan akurat guna pembayaran pasien. Selain itu tidak perlu adanya tim case-mix atau INACBGs pada tingkat RS ataupun Dinas Kesehatan karena hal ini akan menimbulkan inefisiensi sumber daya manusia dan anggaran. Berikut alur proses pembayaran pada sistem pembayaran prospektif.

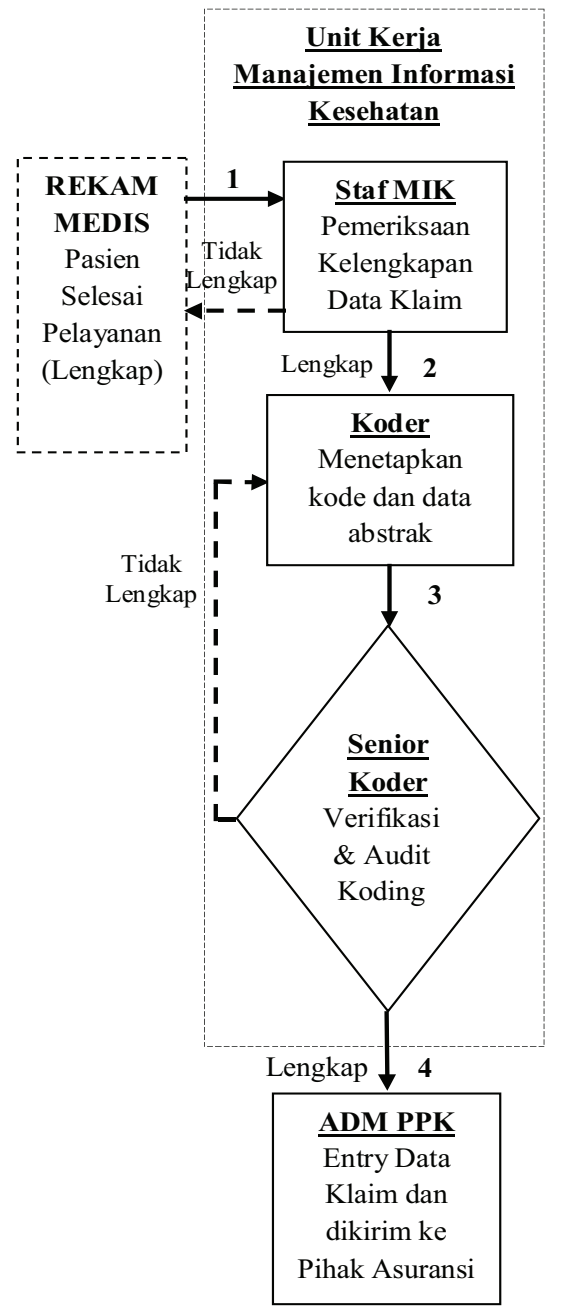

Bagan atau Skema 2. Alur dan Prosedur Klaim Pembayaran Prosfektif 
Skema dari alur dan prosedur pelaksanaan klaim pembayaran prosfektif di atas, sebagai berikut :

a. Setelah pasien keluar dari rumah sakit, dokter harus menuliskan dan memastikan deskripsi narasi dari diagnosa utama dan sekunder dan prosedur tindakan lengkap dan akurat

b. Koder memberikan kodefikasi terhadap diagnosa utama dan sekunder serta prosedur dan data yang dibutuhkan dalam proses klaim secara lengkap dan akurat

c. Senior koding melakukan tahapan koreksi mulai dari melakukan verifikasi dan audit hasil koding dan data abstrak rekam medis yang mengacu pada kode etik pengkodean, yaitu sebagai berikut :

1) Mereview dan menganalisis kesalahan yang ditemukan dan berusaha menelusuri sumbernya.

2) Membandingkan informasi yang dihasilkan pengkode (di lembar resume pulang) saat dikode dengan informasi yang tertera di lembar-lembar catatan klinik saat pengkodean dijalankan

3) Mereview informasi untuk suatu akurasi dan dikaitnya dengan standar nasional yang diberlakukan

4) Mengidentifikasi area praktik pengkodean yang perlu peningkatan

5) Mereview kualitas dan kelengkapan sumber informasi (lembar resume dan lembar catatan klinik)

6) Mempertemukan perbedaan pendapat antara tenaga medis dengan pengkode.

7) Membuat rekomendasi, bila perlu, untuk meningkatkan kualitas dan kode data klinis.

d. Setelah data yang dikoding lengkap dan akurat, maka data tersebut diserahkan ke bagian administrasi pemberi pelayanan kesehatan atau rumah sakit untuk dilakukan entry data klaim.

e. Setelah selesai maka klaim dikirim ke pihak asuransi.

Dengan alur dan prosedur seperti ini tentunya akan lebih banyak melibatkan sumber daya manusia di bagian manajemen informasi kesehatan yang berperan dalam proses klaim tersebut. Serta pihak rumah sakit tidak perlu lagi untuk menyewa jasa konsultan verifikator independen untuk memverifikasi hasil koding karena dengan tinjauan internal yang dilakukan oleh senior koding atau manajer unit informasi kesehatan secara teratur dapat lebih memaksimalkan kualitas data klinis.
Peran profesional MIK sudah sesuai dengan fungsi dan standar profesinya, keuntungan dari proses ini yaitu hasil data klinis untuk proses klaim akan lebih berkualitas, waktu proses klaim akan lebih singkat dan juga tidak banyak membutuhkan sumber daya manusia yang terlibatdan akan mengurangi biaya untuk kegiatan proses klaim.

\section{Sumber Daya Manusia Yang Terlibat Pada Proses Klaim Sistem INA-CBGs}

Dari hasil penelitian, jumlah keseluruhan sumber daya manusia yang terlibat pada proses klaim INA-CBGs di BLUD RSU H. Boejasin Pelaihari adalah 11 orang yang memiliki tugas di dalam Tim Case Mix tersebut berdasarkan kompetensinya masing-masing dan juga telah mendapatkan berbagai pelatihan tentang INA-CBGs secara berkesinambungan. Sumber daya manusia yang terlibat secara langsung dalam proses klaim tersebut yaitu berjumlah 7 orang dan penanggung jawab dan pengawas kegiatan berjumlah 4 orang yang terdiri dari direktur rumah sakit sebagai pembina, kepala bidang pelayanan sebagai pengarah, seorang dokter tetap rumah sakit sebagai ketua tim tersebut dan seorang lulusan kebidanan sebagai sekretaris.

Dilihat dari beban kerja pada proses pengklaiman berkas pasien jamkesmas yang perhari tidak terlalu tinggi, maka sumber daya manusia yang terlibat secara langsung pada proses pengklaiman dapat lebih diefisienkan dengan cara merangkap atau menyederhanakan uraian tugas yang dilakukan oleh 2 orang sumber daya manusia menjadi 1 orang sumber daya manusia yang mengerjakan tahapan tersebut, seperti tahapan melakukan entry data ke sistem software INA-CBGs bisa dilakukan sekaligus dengan melakukan grouping data yang sudah di koding ke dalam software INA-CBGs dan membuat rekap hasil grouper.

\section{Peran Profesional MIK Pada Proses Klaim Sistem INA-CBGs}

Dari hasil penelitian di BLUD RSU H. Boejasin Pelaihari, peran profesional dan unit kerja MIK sebagai koder belum optimal karena menilai atau memverifikasi hasil koding masih dilakukan oleh Verifikator Independen. Tugas dari bagian verifikator independen tersebut adalah memeriksa dan menilai kelengkapan berkas klaim pasien Jamkesmas, memeriksa kelengkapan berkas severity level III serta memeriksa dan menilai input data semua pasien yang telah dientry termasuk koding 
diagnosa dan tindakan yang telah dilakukan oleh koder atau unit RMIK (MIK).

Berdasarkan paradigma baru rekam medis menjadi MIK maka peran professional dan unit MIK adalah:

- Meningkatkan potensi pendapatan rumah sakit dengan menjamin koding yang akurat didukung oleh dokumen yang berkualitas.

- Meningkatkan arus kas (cash flow) rumah sakit dengan memprioritaskan terhadap proses klaim yang ditolak dan banding jika diperlukan.

Secara lebih lengkap peran profesional MIK untuk kedepannya difokuskan pada lima bidang utama fungsional informasi kesehatan, (AHIMA, 2011):

a. Penangkapan, keakuratan dan pemeliharaan data

Pengembangan danpelaksanaan praktek sesuai standar dan kebijakan serta prosedur yang mendukung pengambilan data yang akurat, handal dan tepat waktu. Merencanakan strategi dan implementasikan data yang berkualitas dan terintegrasi pada manajemen struktur data yang diperlukan untuk mendukung arus informasi yang optimal.

b. Analisis Data/Informasi dan Pendukung Keputusan

Pengembangan dan pelaksanaan praktik standar, kebijakan dan prosedur yang memungkinkan untuk melakukan analisis yang handal dan efektif, transformasi dan pelaporan data maupun informasi untuk perawatan pasien, meningkatkan kualitas kesehatan, memajukan penelitian dan kegiatan pendukung lainnya.

c. Menyediakan Informasi dan Sebagai Penghubung

Penyusunan danpenyediaan informasi, laporan, dan pengetahuan lainnyadidukung data yang berkualitas.Dengan fungsi yang terkait dalam penyediaandan pelaporan praktek yang berkaitan dengan data, informasi dan pengetahuan dasar.

d. Sumber ManajemenInformasiKesehatan dan Perubahan

Memastikan bahwa petugas kesehatan sudahterdidik tentang MIK,proses di dalam MIK, tanggung jawab dan kepatuhan untuk mengelola data kesehatan dengan baik. Serta menerapkan kemajuan dan perubahan didalam proses MIK.

e. Tata kelola dan Pengelolaan informasi Menyediakan kebijakan organisasidan kepatuhan dalam proses pengambilan keputusan, hak dan tanggung jawab. Dengan memastikan penggunaandan pengelolaan informasi kesehatan sesuai dengan hukum, peraturan,standar, dan kebijakan organisasi. Untuk itu peran dan fungsi profesional MIK yaitu melindungi dan menjamin penggunaan sesuai dengan etika informasi kesehatan.

Selain itu, yang menjadi tanggung jawab profesional MIK juga berkaitan dengan Kebijakan, Standar, Penelitian dan Pendidikan.Peran utama profesional MIK tersebut dalamgambarberikut:

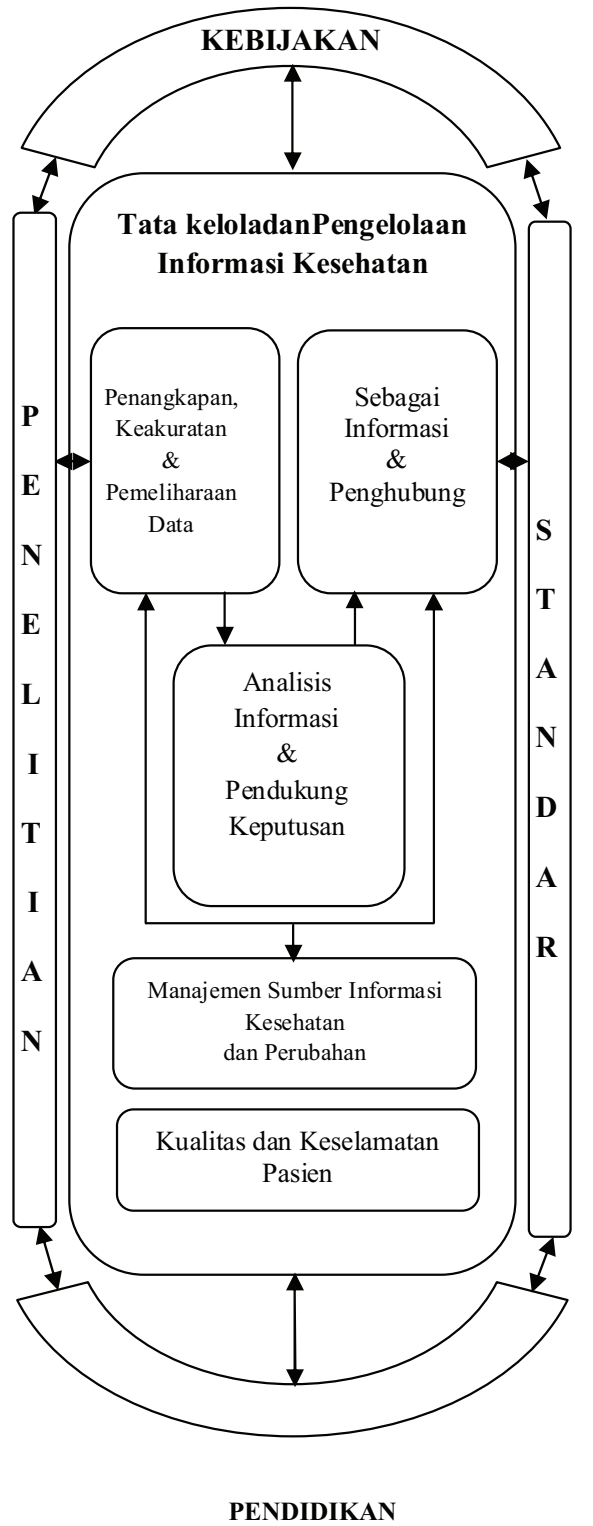

Gambar 1. Peran dan Fungsi Utama Profesional Manajemen Informasi Kesehatan.

Sumber:American Health Information Management Association (AHIMA), 2011 
Dilihat dari peran dan fungsi profesional MIK diatas, maka hal tersebut sudah sejalan dengan kebutuhan akan data klinis yang akurat dan lengkap yang diperlukan dalam proses klaim sistem INACBGs, maka untuk itu diperlukan tanggung jawab penuh dari manajer unit informasi kesehatan atau senior koding untuk melakukan tahapan mulai dari pengawasan, koreksi, membuat kebijakan atau prosedur dan melakukan proses audit internal/ audit diagnosis. Untuk itu kualitas kodedata klinis dari profesional MIK juga harus mengacu pada standar etika koding sehingga hasil kode data klinis mengandung unsur-unsur yaitu (Latour-Maki, 2010):

a. Keandalan yaitu sejauh manadata dapat diperbanyak oleh pengukuran selanjutnya atau tes (misalnya, kode data klinis dianggap dapat diandalkan ketika beberapa koder menetapkan kode yang sama untuk dicatat).

b. Validitas yaitu sejauh manadata dikodekan secara akurat mencerminkan diagnosa dan prosedur pasien.

c. Kelengkapan yaitu sejauh manadata dikodekan mewakili semua diagnosa pasien atau prosedur yang relevan.

d. Ketepatan waktu yaitu sejauh manadata dikodekan tersedia dalam jangka waktu yang diperlukan untuk tujuan penagihan, pendukung keputusan dan kegunaan lainnya.

Kualitas dari kode data klinis dari profesional MIK juga dipengaruhi oleh beberapa faktor (Latour-Maki, 2010):

a. Pelatihan yang memadaibagi semua orang yang terlibat dalam proses koding, termasuk koder, koding pengawas, dokter dan tenaga keuangan.

b. Acuandan sumber daya pendukung yang Cukup, termasuk buku-buku koding yang up-to-date, serta dalam penerbitan pedoman resmi dan perangkat lunak pendukung lainnya.

c. Dokumentasi klinis yang akurat dan lengkap yang mencakup setiap kondisi yang bersangkutan dan pelayanan yang diberikan kepada pasien.

d. Adanya dukungan para manajer senior, yang harus memahami betapa pentingnya fungsi koding adalah untuk keberlangsungan organisasi yang terus menerus.

e. Sebuah rencana perbaikan kinerja untuk fungsi koding yang menjamin proses perbaikan kualitas berkesinambungan.

Peran profesional MIK dalam memberikan kode data klinis sangat menentukan logic software, kesalahan penulisan ataupun pemberian kode pada diagnosis akan mempengaruhi tarif. Sistem yang tersediamenggunakan kombinasidiagnosisprimer danberbagai faktorlainnya(termasukdiagnosaseku nder, prosedur, usia, jenis kelamindanklinis) untuk menentukan tingkat keparahan(level severity) yang diderita oleh pasien, untuk itu profesional MIK adalah kunci ataupemeran penting dalamkegiatanproses tersebut (Skurka, 2003).

Dengan adanya profesional MIK pada proses klaim sistem INA-CBGs, maka tugas atau peran senior koding juga dibutuhkan untuk melakukan tahapan koreksi mulai dari melakukan verifikasi dan audit hasil koding dan data abstrak rekam medis yang mengacu pada kode etik pengkodean, yaitu (Hatta, 2010):

a. Melakukan auditing dan monitoring internal

b. Mengimplementasikan compliance dan standar praktik

c. Menentukan kontak person compliance

d. Mengadakan pelatihan dan pendidikan yang tepat

e. Melakukan tanggapan dengan tepat atas keluhan yang terdeteksi dan mengambil tindakan koreksinya

f. mengembangkan jalur komunikasi yang terbuka

g. Membuat standar disiplin dalam pedoman tertulis

Proses verifikasi formulir klaim yang dikoding oleh koder menurut alur dan prosedur proses klaim INA-CBGs dirumah sakit dan pedoman pelaksanaan jamkesmas yaitu menggunakan jasa konsultan verifikator independen, namun dilihat dari peran profesional MIK yaitu dapat menyediakan kode data klinis yang lengkap dan akurat dengan cara adanya senior koder yang bertanggung jawab penuh dalam melakukan verifikasi hasil dari setiap koding yang dilakukan oleh koder, maka tugas dari verifikator independen di rumah sakit dalam memverifikasi hasil koding yang dilakukan koder dapat digantikan oleh senior koder atau manajer MIK.

\section{SIMPULAN}

Alur dan prosedur proses klaim sistem INA-CBGs di BLUD RSU H. Boejasin Pelaihari melibatkan berbagai bidang mulai dari Bagian Pelayanan, Bagian Rekam Medis, Bagian Jamkesmas sampai dengan Verifikator Independen. Alur tersebut belum sesuai dengan pelaksanaan klaim pembayaran prosfektif, banyak terjadi pengulangan kegiatan sehingga dapat memperlambat proses klaim.

Jumlah SDMdalam tim case-mix di BLUD RSU H. Boejasin Pelaihari sebanyak 11 orang, namun yang terlibat secara langsung pada proses klaim yaitu sebanyak 7 orang. Dengan jumlah pasien jamkesmas rata-rataper hari 10 orang pasien maka jumlah SDM yang terlibat dalam kegiatan klaim dapat dikurangi, 
Dedy, dkk. The Role og Health Information Management

bahkan seharusnya tidak perlu ada tim case-mix karena hal ini menjadi kegiatan rutin pada sistem pembayaran prospektif.

Ka. Bagian Rekam Medis sebagai anggota tim case-mix bertugas memverifikasi dan memberi kode INA-CBGs dalam berkas klaim, namun kenyataannya hal ini dilakukan oleh seorang koder dengan kualifikasi S1 Kesehatan Masyarakat dan hasil koding tersebut diverifikasi oleh verifikator independen. Hal ini masih belum sesuai dengan peran profesional MIK dalam reimbursement, bahwa proses verifikasi atau audit koding dapat dilakukan oleh senior koder atau Ka. Bagian RMIK, dengan cara audit koding diagnosis yang dilakukan secara rutin dan berkesinambungan.

\section{DAFTAR PUSTAKA}

American Health Information Management Association (AHIMA) House of Delegates. Standards of Ethical Coding.(2008), www.library. ahima.org/xpedio/grups/public/documents/ahima/ bok2 001166.hcsp?dDocName=bok2 001166 (Diakses Pada 7 Mei 2013)

American Health Information Management Association (AHIMA) House of Delegates. Code of Ethic.(2011), www.library.ahima. org/xpedio/grups/public/documents/ahima/ bok1 024277.hcsp?dDocName=bok1 024277 (Diakses Pada 26 Juni 2013)

American Health Information Management Association (AHIMA) A New View of HIM: Introducting the Core Model.(2011). www.library.ahima.org/xpedio/grups/public/ documents/ahima/bok1 049283pdflibrary. ahima.org. (Diakses Pada 29 Mei 2013)

Departemen Kesehatan RI. 2008. Petunjuk Teknis Administrasi Klaim dan Verifikasi Program Jaminan Kesehatan Masyarakat 2008. Jakarta: Departemen Kesehatan RI

Farenholz Cheryl G, Russo Ruthann, (2013). Documentation for Health Records, Chicago, Illinois: AHIMA.

Hatta, Gemala R. (2010). Pedoman Manajemen Informasi Kesehatan di Sarana Pelayanan Kesehatan Edisi Revisi, Universitas Indonesia, Jakarta.

Hers h William, Health and Biomedical Informatics: Opportunities and Challenges for a TwentyFirst Century in Profession and its Education. "Yearbook of Medical Informatics (2008)",
157-164. http://www/ncbi.nlm.nih.gov/ pubmed/18660890

Hosizah, (2013), “Kesiapan Pendidikan dan Profesi Perekam Medis untuk Implementasi Jaminan Kesehatan Semesta, Makalah Seminar "Health Information System to Succeed The Enactment of Indonesia Universal Health Coverage", FIKI, 24 April 2013

Hosizah, (2013),Dokumen Rekam Medis: Aspek Penting dalam Implementasi Sistem Jaminan Sosial Nasional, makalah seminar di RSUD Dr. H.Moch Ansari Saleh Banjarmasin, 4 Juli 2013

Huffman, EdnaK.(1994). HealthInformation Management. Berwyn,Illionis: Physicians' Record Company.

International Federation of Health Information Management Associations (IFHIMA), 2012. Education Module for Health Records Practice.

Kathleen M. LaTour \& Shirley E. Maki (2010) Health Information Management concepts, principles, and practice. Third Edition. Chicago, Illionis: American Health Information Management Association (AHIMA).

Menteri Kesehatan RI. (2012). Peraturan Menteri Kesehatan Republik Indonesia Nomor 40 Tahun 2012 tentang Pedoman Pelaksanaan Program Jaminan Kesehatan Masyarakat 2012. Jakarta: Departemen Kesehatan RI.

Menteri Kesehatan RI. (2008). Peraturan Menteri Kesehatan Republik Indonesia Nomor.269/ MENKES/PER/III/2008.tentangRekam Medis. Jakarta: Departemen Kesehatan RI.

Menteri Kesehatan RI. (2007). Keputusan Menteri Kesehatan Republik Indonesia Nomor.377/ Menkes/SK/III/2007 tentang Standar Profesi Perekam Medis dan Informasi Kesehatan. Jakarta: Departemen Kesehatan RI.

Notoadmodjo, S. (2012).Metodologi Penelitian Kesehatan Edisi Revisi. Rineka Cipta. Jakarta.

Peta Jalan Jaminan Kesehatan Nasional 2012-2019

Skurka, Margaret A. 2003. Health Information Management, Principles and Organization of Health Information Services, $5^{\text {th }}$ ed. Chicago: AHA Press Health Forum Inc.

Undang-undang No.40 Tahun 2004 tentang Sistem Jaminan Sosial Nasional.

Undang-undang No.24 Tahun 2011 tentang Badan Penyelenggara Sosial Nasional. Wikipedia. Teori Peran. http://id.m.wikipedia.org/wiki/ teori_peran.. (Akses Pada 29 Mei 2013). 